\title{
Treatment efficiency of resistant hypertension in cardiologist's office
}

\author{
Dlesk A, Kamensky G, Stefanik M, Kuzma M, Pernicky M \\ 5th Department of Internal Medicine, Faculty of Medicine of Comenius University and University \\ Hospital Bratislava,Bratislava, Slovakia.dleskant@hotmail.com
}

\begin{abstract}
Background: The target values of blood pressure have not been achieved in our population of patients sufficiently. The most difficult is a control of patients with resistant hypertension. We do not have data about efficiency treatment of these patients today.

Objectives: The aim of our study was to assess current treatment status and by antihypertensive treatment modification we tried to reach an adequate blood pressure control.

Methods: Fifty two patients suffering from resistant hypertension 2-3 degree ESC/ESH with high cardiovascular risk have been observed. Reaching of the target blood pressure values was verified by 24-hour ambulatory blood pressure monitoring.

Results: The target blood pressure values were achieved in $50 \%$ of patients during 18 months. We noticed a statistically significant difference $(p<0.001)$ in a decrease of casual and 24-hour ambulatory blood pressure in the group of controlled hypertensive patients in comparison with a group where blood pressure did not decrease sufficiently. In case of $50 \%$ patients, the target blood pressure values have not been reached in spite of more antihypertensive drugs and a higher dose.

Conclusion: Adequately and systematically controlled patients were treated less intensively in comparison with an inadequately controlled group. 24-hour blood pressure monitoring analysis confirmed correction of the patological diurnal rhythm mostly in adequate blood pressure controlled group. In this group, we have noticed a statistically significant decrease of blood urea and creatinin levels and albumin/creatinin ratio in urine. Resistant hypertension needs multi-faceted approach with consistent control of all comorbidities in a case of problematic blood pressure control (Tab. 6, Fig. 1, Ref. 21). Text in PDF www.elis.sk.

Key words: chronotherapy, 24-hour ambulatory blood pressure monitoring, diurnal blood pressure profile.
\end{abstract}

Hypertension is among the risk factors of atherosclerosis, not only as a cause of total mortality, but as well as coronary artery disease mortality, stroke, heart failure, peripheral artery obliteration disease and renal failure. In accordance with data in the year of 2000 , about billion of people suffer from hypertension in the world (1/3 in developed, $2 / 3$ in developing countries) (1). The systolic blood pressure (BP) control is not satisfactory in most of patients and lower values $(<130 \mathrm{mmHg})$ recommended in diabetic patients and high risk patients are reached rarely, which refers to high mortality and morbidity (2).

The prevalence of hypertension is growing in Slovakia and in accordance with the CINDI program $(3,4)$ has a large proportion in Europe (41\%). The number of hospitalizations has been continuously growing because of poor hypertension control, the incidence of new acute coronary syndromes and stroke did not decrease. Clinical and epidemiological KESHSR trial in 2006 (3, 5) showed that out of each ten hypertensive patients, used antihypertensive drug has proved as non-effective treatment in 7 of them

5th Department of Internal Medicine, Faculty of Medicine of Comenius University and University Hospital Bratislava, Bratislava, Slovakia

Address for correspondence: A. Dlesk, MD, 5th Department of Internal Medicine, Faculty of Medicine of Comenius University and University Hospital Bratislava, Ruzinovska 6, SK-821 01 Bratislava, Slovakia. Phone: +421.915 .749945$
(6). Only $21 \%$ of treated hypertensives are well controlled $(7,8)$. To evaluate a management of high-risk patients in Slovakia, the project ARTEHYP-SK has been established.

BP control in patients with resistant hypertension seems to be the most problematic. The most difficult is to control systolic BP. Hypertension has been defined as resistant to treatment when a therapeutic plan that has included attention to lifestyle measures and the prescription of $\geq 3$ antihypertensive drugs in adequate doses has failed to lower systolic and diastolic BP sufficiently. One of used drugs should be a diuretic (9). The prevalence of resistant hypertension has not been known, but it is not rare. It occurs in $20-30 \%$, some authors said (10). There are many causes, but the most impact predictive factors of less controlled blood pressure has not been defined. Cardiovascular risk and mortality in patients with resistant hypertension is high.

The aim of our study was to assess current treatment status and by antihypertensive treatment modification we tried to reach goal $\mathrm{BP}$ values. The diurnal profile of BP was also monitored in order to define the relationship between pathological diurnal rhythm correction and high BP control.

\section{Inclusion and exclusion criteria}

Patients with causal systolic BP $\geq 160 \mathrm{mmHg}$ or diastolic BP $\geq 100 \mathrm{mmHg}$ and a high cardiovascular risk were observed. Each 
of them had minimal 3 out of the following risk factors: smoking, obesity, hyperlipoproteinemia, positive family history (myocardial infarction, stroke by the age of 50 years in case of men, and 55 years in case of women) or target organ damage, diabetes, cardiovascular or renal diseases. The secondary reasons of hypertension were excluded. Each of them had used minimal 3 antihypertensive drugs (within diuretic). On the base of 24-hour ambulatory BP monitoring, we divided the patients in to controlled and uncontrolled group.

All 52 patients followed in this study were included in the nationwide the ARTEHYP-SK project, which is still ongoing.

\section{Methods}

At the beginning, after 12 and 18 months of follow-up, each patient was examined by a physician (cardiologist), laboratory tests and 24-hour ambulatory BP monitoring were performed. During the physical examination, BP, pulse rate, height, weight and waist circumference were measured. BP was measured in two sequences, with acceptance of the second. Following biochemistry parameters were evaluated: glucose, creatinin, urea, uric acid, potassium, total cholesterol, LDL cholesterol, HDL cholesterol, triglycerides and albumin/creatinin ratio in urine. Blood samples were analysed in Medirex a.s. labs. Daily and nocturnal periods were firmly determined, daily period from 07:00 AM to 09:59 PM and nocturnal period from 10:00 PM to 06:59 AM. 24-hour ambulatory BP was performed with a properly calibrated SunTech device. BP was automatically measured every 30 minutes during the day and every 60 minutes during the night. Participants were instructed to do their usual activities with minimal restrictions. At the end of the trial, patients were divided into the two groups according to the BP control. Controlled hypertensives were those with casual BP $<140 / 90 \mathrm{mmHg}$ and mean 24-hour ambulatory BP <35/85 mmHg. Controlled subjects with diabetes mellitus were those with mean 24-hour ambulatory $\mathrm{BP}<130 / 80 \mathrm{mmHg}$.

In order to assess the treatment intensity in the morning or evening, doses of drugs had to be considered. Doses of drugs were standardised at first by maximal recommended daily doses presented in SPC. The rate of used drug dose to its maximal recommended daily dose is expressed by recommended daily dose index (RDDI). RDDI in patients using more than one antihypertensive drug was calculated as rate of standard daily antihypertensive drug dose summary and number of used drugs. RDDI in patients using one drug in its maximal recommended daily dose was 1.0. With decreasing doses it was proportionally going down. There was a linear relationship between antihypertensive drug and RDDI.

\section{Statistical methods}

The patients were included into follow-up since November 2009 to June 2010. For statistical purposes, the data from the first 18 months were included. Interval variables were compared by the Student's paired t-test. Nominal and interval variables were compared by independent t-test. Nominal variables were compared by non-parametric $\chi^{2}$ test. A $p \leq 0.05$ was taken as the level of statistical significance. For statistical analyses, the SPSS software were used.

\section{Results}

Demographic characteristics and analytical parameters

52 patients ( 27 men, 25 women) from two cardiologist's offices all with resistant hypertension with the mean age 65 years were observed. Several cardiovascular risk factors were presented in all patients simultaneously, especially obesity (100\%), dyslipidemia (65\%) and diabetes mellitus (50\%). Smokers represented $42 \%$ of all subjects. Majority of patients had a target organ damage $(82 \%)$, history of cardiovascular or renal disease $(78 \%)$ and more than half (53\%) had documented chronic kidney disease. In term of sex, men were more often smokers and had prior myocardial infarction. Women had more often documented diabetes mellitus and a target organ damage (Tab. 1).

Tab. 1. Demographic characteristics of patients at baseline and after follow-up.

\begin{tabular}{lccc}
\hline & $\begin{array}{c}\text { Whole } \\
\text { group }\end{array}$ & Men & Women \\
\hline Patients, n & 52 & 27 & 25.04 \\
Smoking, \% & 42.31 & 48.15 & 36.13 \\
Obesity, \% & 100 & 100 & 92.35 \\
Dyslipidemia, \% & 92.86 & 92.59 & 92.07 \\
Diabetes mellitus, \% & 50 & 37.04 & 56.1 \\
Target organ damage, \% & 82.14 & 74.07 & 88.3 \\
& & & \\
Cardiovascular or renal disease, \% & 78.26 & 55.56 & 76.41 \\
Status after myocardial infarction, \% & 42.86 & 51.85 & 32.15 \\
History of stroke, \% & 21.43 & 14.81 & 12.09 \\
Chronic heart failure, \% & 32.14 & 29.63 & 28.13 \\
Chronic kidney disease, \% & 53.57 & 51.85 & 60.07 \\
\hline
\end{tabular}

Tab. 2. Basic analytical characteristics of patients at baseline and after follow-up.

\begin{tabular}{lccc}
\hline Variable & Baseline & Follow-up & P-value \\
\hline BMI, $\mathrm{kg} / \mathrm{m}^{2}$ & $32.21 \pm 6.23$ & $31.66 \pm 6.39$ & $\mathrm{P}=0.05$ \\
Waist circumference, cm & $104.78 \pm 11.29$ & $103.63 \pm 12.92$ & $\mathrm{P}=0.016$ \\
& & & \\
Clinic SBP, mmHg & $161.6 \pm 12.12$ & $138.08 \pm 14.63$ & $\mathrm{P}<0.001$ \\
24-hour mean of SBP & $151.94 \pm 18.13$ & $135.96 \pm 16.2$ & $\mathrm{P}<0.001$ \\
Daily mean of SBP & $154.25 \pm 18.24$ & $139.06 \pm 16.92$ & $\mathrm{P}<0.001$ \\
Nocturnal mean of SBP & $138.62 \pm 16.83$ & $128.1 \pm 19.27$ & $\mathrm{P}=0.001$ \\
Clinic DBP, mmHg & $94.71 \pm 9.52$ & $82.6 \pm 8.13$ & $\mathrm{P}<0.001$ \\
24-hour mean of DBP & $84.17 \pm 13.49$ & $75.96 \pm 10.66$ & $\mathrm{P}<0.001$ \\
Daily mean of DBP & $85.52 \pm 13.92$ & $78.9 \pm 12.01$ & $\mathrm{P}=0.001$ \\
Nocturnal mean of DBP & $76.38 \pm 13.64$ & $69.67 \pm 12.14$ & $\mathrm{P}=0.002$ \\
\hline
\end{tabular}

Tab. 3. Treatment characteristics of controlled hypertensive patients at baseline and after follow-up.

\begin{tabular}{|c|c|c|c|c|}
\hline \multirow{2}{*}{ Variable } & \multicolumn{2}{|c|}{ Baseline } & \multicolumn{2}{|c|}{ Follow-up } \\
\hline & Morning & Evening & Morning & Evening \\
\hline Average number of drugs (total), $\mathrm{n}$ & \multicolumn{2}{|c|}{4.14} & \multicolumn{2}{|c|}{4.5} \\
\hline Average number of drugs, $n$ & 3.68 & 2.5 & 3.07 & 3.18 \\
\hline Treated with 2 drugs, $\%$ & \multicolumn{2}{|c|}{0} & \multicolumn{2}{|c|}{7.1} \\
\hline Treated with 3 drugs, $\%$ & \multicolumn{2}{|c|}{42.9} & \multicolumn{2}{|c|}{14.3} \\
\hline Treated with 4 drugs, $\%$ & \multicolumn{2}{|c|}{28.6} & \multicolumn{2}{|c|}{39.3} \\
\hline Treated with 5 drugs, $\%$ & \multicolumn{2}{|c|}{10.7} & \multicolumn{2}{|c|}{17.9} \\
\hline Treated with 6 drugs, $\%$ & \multicolumn{2}{|c|}{7.1} & \multicolumn{2}{|c|}{10.7} \\
\hline Treated with 7 drugs, $\%$ & \multicolumn{2}{|c|}{10.7} & \multicolumn{2}{|c|}{7.1} \\
\hline Treated with 9 drugs, $\%$ & \multicolumn{2}{|c|}{0} & \multicolumn{2}{|c|}{3.6} \\
\hline
\end{tabular}


Patients who did not reach goal BP values during the followup had in comparison with well controlled hypertensive patients a higher prevalence of dyslipidemia (95.83\% vs $92.86 \%)$, target organ damage (91.67\% vs $82.14 \%$ ) and chronic kidney disease (58.33\% vs $53.57 \%$ ). The average age of all patients were 65 years, in men 64.4 years and in women 65.6 years. The mean office BP in patients at baseline was $161.6 / 94.7 \mathrm{mmHg}$. The mean 24-hour ambulatory BP was 151.9/84.2 $\mathrm{mmHg}$, daily 154.3/85.5 $\mathrm{mmHg}$ and nocturnal 138.6/76.4 $\mathrm{mmHg}$.

By modification of antihypertensive treatment during the follow-up we noticed a significant reduction of casual BP (23.52/12.11 $\mathrm{mmHg}$ for systolic $\mathrm{BP} /$ diastolic $\mathrm{BP}, \mathrm{p}<0.001$ ) in comparison to initial values as well as 24-hour ambulatory BP monitoring $(15.98 / 8.21 \mathrm{mmHg}$ for systolic BP/diastolic BP, $\mathrm{p}<0.001)$. The average number of antihypertensive drug increased from initial 4.15 to 4.69 mainly due to evening administration. At baseline, patients were treated mostly by group of 3 and 4 antihypertensive drugs, however, at the end of follow-up by a group of 4 and 5 classes. We noticed a moderate, but statistically significant reduction of weight $(-0.88 \mathrm{~kg}, \mathrm{p}=0.032)$, BMI $\left(-0.55 \mathrm{~kg} / \mathrm{m}^{2}, \mathrm{p}=0.05\right)$, and waist circumference $(-1.15 \mathrm{~cm}, \mathrm{p}=0.016)$. Biochemistry parameters in all patients did not change significantly (Tab. 2).

\section{Group 1: patients with controlled hypertension}

Of all subjects, we reached goal BP values in 28 hypertensive patients. At baseline, diuretics (24.1\%), ACE inhibitors (19\%) and betablockers $(17.2 \%)$ were prescribed predominantly. The most often $3(42.9 \%), 4(28.6 \%)$ and $5(10.7 \%)$ classes of drugs were used. The average number of drugs was 4.14 . Patients were treated more often (3.68 vs 2.5) and also more intensively (RDDI $0.52 \mathrm{vs} 0.28$ ) in the morning. According to ambulatory BP monitoring, we noticed a disturbed diurnal profile of blood pressure in a case of $32 \%$ subjects.

During the follow-up, diuretics (19.5\%), ACE inhibitors $(17.1 \%)$ and beta blockers (15.4\%) still remained the most frequently prescribed antihypertensive drugs, prescription of aliskiren and also imidazole receptor agonists and uradipil increased. The most often 4 (39.3\%), 5 (17.9\%) and $3(14.3 \%)$ classes of drugs were used. The average number of drugs increased to 4.5 . Bedtime antihypertensive drugs dosage increased by $40 \%$, whereas the morning dosage by $39.7 \%$. Pathological diurnal profile of blood pressure was reduced by $31.3 \%$. Review of the treatment characteristics shows Table 3 .

\section{Group 2: patients with uncontrolled hypertension}

Despite of antihypertensive treatment modification during the follow-up, the goal BP values was not reached in 24 patients. At baseline, diuretics (24\%), ACE inhibitors (18\%) and beta blockers $(15 \%)$ were the most frequent used antihypertensive drugs. The most often were used 3 (45.8\%), 5 (20.8\%) and 6 (20.8\%) classes of drugs. Average number of drugs was 4.17 . The patients were treated more often ( 3.13 vs 2.46 ) and more intensively (RDDI 0.47 vs 0.33 ) in the morning. 24-hour ambulatory BP monitoring showed disturbed diurnal profile of blood pressure in a case of $46 \%$ subjects.
Tab. 4. Treatment characteristics of uncontrolled hypertensive patients at baseline and after follow-up.

\begin{tabular}{|c|c|c|c|c|}
\hline \multirow{2}{*}{ Variable } & \multicolumn{2}{|c|}{ Baseline } & \multicolumn{2}{|c|}{ Follow-up } \\
\hline & Morning & Evening & Morning & Evening \\
\hline Average number of drugs (total), $n$ & \multicolumn{2}{|c|}{4.17} & \multicolumn{2}{|c|}{4.92} \\
\hline Average number of drugs, $\mathrm{n}$ & 3.13 & 2.46 & 3.67 & 3.46 \\
\hline Treated with 2 drugs, $\%$ & \multicolumn{2}{|c|}{0} & \multicolumn{2}{|c|}{7.1} \\
\hline Treated with 3 drugs, $\%$ & \multicolumn{2}{|c|}{45.8} & \multicolumn{2}{|c|}{33.3} \\
\hline Treated with 4 drugs, $\%$ & \multicolumn{2}{|c|}{12.5} & \multicolumn{2}{|c|}{20.8} \\
\hline Treated with 5 drugs, $\%$ & \multicolumn{2}{|c|}{20.8} & \multicolumn{2}{|c|}{17.9} \\
\hline Treated with 6 drugs, $\%$ & \multicolumn{2}{|c|}{20.8} & \multicolumn{2}{|c|}{8.3} \\
\hline Treated with 7 drugs, $\%$ & \multicolumn{2}{|c|}{0} & \multicolumn{2}{|c|}{25} \\
\hline
\end{tabular}

Tab. 5. Analytical characteristics of controlled and uncontrolled hypertensive patients after follow-up.

\begin{tabular}{lccc}
\hline Variable & $\begin{array}{c}\text { Uncontrolled } \\
\text { hypertension }\end{array}$ & $\begin{array}{c}\text { Controlled } \\
\text { hypertension }\end{array}$ & p-value \\
\hline Sex, \% men & 50 & 54 & \\
Age, years & $66.71 \pm 10.6$ & $63.57 \pm 10.69$ & $\mathrm{NS}$ \\
BMI, kg/m ${ }^{2}$ & $32.36 \pm 6.2$ & $30.66 \pm 5.18$ & $\mathrm{NS}$ \\
Waist circumference, cm & $109 \pm 13.32$ & $104.36 \pm 12.8$ & $\mathrm{NS}$ \\
& & & \\
Clinic SBP, mmHg & $144.79 \pm 14.48$ & $132.32 \pm 12.28$ & $\mathrm{P}<0.002$ \\
24-hour mean of SBP & $149.29 \pm 10.14$ & $124.54 \pm 10.72$ & $\mathrm{P}<0.001$ \\
Diurnal mean of SBP & $152 \pm 11.1$ & $127.96 \pm 12.62$ & $\mathrm{P}<0.001$ \\
Nocturnal mean of SBP & $143 \pm 16.24$ & $115.32 \pm 10.48$ & $\mathrm{P}=0.001$ \\
Clinic DBP, mmHg & $86.04 \pm 7.66$ & $79.64 \pm 7.45$ & $\mathrm{P}<0.004$ \\
24-hour mean of DBP & $81.75 \pm 9.49$ & $71 \pm 9.08$ & $\mathrm{P}<0.001$ \\
Diurnal mean of DBP & $84.96 \pm 10.85$ & $73.71 \pm 10.56$ & $\mathrm{P}=0.001$ \\
Nocturnal mean of DBP & $76.96 \pm 12.28$ & $63.43 \pm 7.89$ & $\mathrm{P}=0.001$ \\
\hline Data are shy
\end{tabular}

Data are shown as mean \pm standard deviation

$\mathrm{BMI}$ - body mass index; $\mathrm{SBP}$ - systolic blood pressure; $\mathrm{DBP}$ - diastolic blood pressure

During the follow-up, ACE inhibitors (17.6\%), diuretics $(16.8 \%)$ and beta blockers (16\%) still remained the most frequently prescribed antihypertensive drugs. Prescription of imidazole receptor agonists slightly increased, contrawise, prescription of diuretics decreased. Most often 3 (33.3\%), 7 (25\%) and $4(20.8 \%)$ classes of drugs were used. The average number of drugs increased to 4.95 . Bedtime antihypertensive drugs dosage increased by $47.7 \%$, morning dosage by $21.4 \%$. Pathological diurnal profile of BP was reduced in $17.4 \%$. Review of the treatment characteristics showed Table 4.

\section{Comparison between the groups}

In the group of controlled hypertensive patients we noticed a statistically significant difference in a decline of casual BP values in comparison to the group with uncontrolled hypertension. A statistically significant difference $(p<0.001)$ in a decline of BP values was noticed among subjects during ambulatory BP monitoring for 24-hour, diurnal and nocturnal period (Tab. 5).

At baseline, both groups of patients were treated almost with the same number of antihypertensive drugs, but more frequently and also more intensively in the morning. The most frequent used antihypertensive drugs in both groups were diuretics, ACE inhibitors and beta blockers. During the follow-up we noticed significant differences between morning and evening dosing. In both groups a new drug administration and current drug dose up-titration was 
Tab. 6. Characteristics of controlled and uncontrolled hypertensive patients according to RDDI at baseline and after follow-up.

\begin{tabular}{lcc}
\hline Variable & $\begin{array}{c}\text { Uncontrolled } \\
\text { hypertension }\end{array}$ & $\begin{array}{c}\text { Controlled } \\
\text { hypertension }\end{array}$ \\
\hline At baseline & & \\
RDDI of used drugs (total) & $0.8073 \pm 0.1855$ & $0.7958 \pm 0.2690$ \\
RDDI of drugs after awakening & $0.4719 \pm 0.1632$ & $0.5289 \pm 0.1648$ \\
RDDI of drugs at bedtime & $0.333 \pm 0.224$ & $0.2847 \pm 0.1884$ \\
& & \\
After follow-up & & \\
RDDI of used drugs (total) & $0.9876 \pm 0.2358$ & $0.7704 \pm 0.2439$ \\
RDDI of drugs after awakening & $0.5121 \pm 0.2184$ & $0.3821 \pm 0.2055$ \\
RDDI of drugs at bedtime & $0.4528 \pm 0.1339$ & $0.373 \pm 0.1538$ \\
\hline RDDI - recommended daily dose index &
\end{tabular}

RDDI - recommended daily dose index

observed mainly at bedtime and in the group of uncontrolled hypertensives also after awakening. In the group of uncontrolled hypertensive patients we didn't reach goal BP values despite of using almost 5 classes of antihypertensive drugs in their maximal recommended daily doses (RDDI 0.98). However, in comparison with baseline values, we reached a certain decline in blood pressure values also in this group of patients. We noticed a correction of pathological diurnal rhythm of blood pressure in well controlled hypertensives by $31.3 \%$, whereas in the group of uncontrolled hypertensives by only $17.4 \%$.

In the group of controlled hypertensive patients we noticed a statistically significant decline of blood urea $(8.36 / 6.87 \mathrm{mmol} / \mathrm{l}$; $\mathrm{p}=0.033)$ and creatinine $(90.7 / 80.53 \mu \mathrm{mol} / \mathrm{l} ; \mathrm{p}=0.043)$ levels and albumin/creatinin ratio in urine $(5.42 / 2.19 \mathrm{mg} / \mathrm{mmol} ; \mathrm{p}=0.029)$ (Tab. 6).

\section{Discussion}

Intensification of the antihypertensive treatment in the group of 52 high-risk patients with the resistant hypertension led to an adequate BP control only in $50 \%$ of patients after 18 months of follow-up. The target BP values in the group of uncontrolled hy-

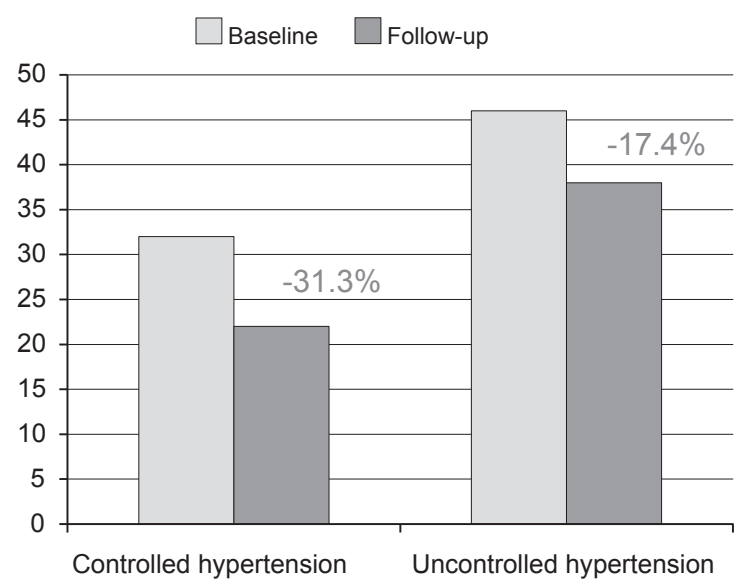

Fig. 1. Prevalence of a nondipper profile of blood pressure in patients with controlled and uncontrolled hypertension at baseline and after follow-up pertensive patients was not achieved despite the higher number of antihypertensive drugs and their doses. Well controlled hypertensive patients needed less intensive treatment in comparison with uncontrolled patients. Perindopril arginin/indapamid (a fixed combination), bisoprolol and amlodipin were the most frequent antihypertensive drugs used in this group of patients. In the group of uncontrolled hypertensive patients indapamid, telmisartan, trandolapril and perindopril arginin/indapamid were the most frequent antihypertensive drugs used. Our results have shown that the intensity of the antihypertensive treatment does not guarantee a successful BP control in all resistant hypertensive patients. On the other hand, we have noticed a mild decrease in BP in these groups of patients. The reasons for the resistance to treatment are different, the most frequent causes are: little cooperation in case of therapy and lifestyle changes, presence of severe organ damage, volume overload and others. The incidence of target organ damage, chronic kidney disease and hyperlipoproteinemia were frequent in the group of uncontrolled hypertensive patients what is presumably one of several causes of resistance to treatment.

24-hour ambulatory BP monitoring can reveal circadian rhythm disturbances. The relation between pathological diurnal profile and organ damage is well known. The decline of nocturnal BP values by $10-20 \%$ (dipping) is a physiological component of diurnal BP rhythm. Its absence (non-dipping) is frequent in patient with resistant hypertension and is associated with target organ damage $(11,12)$ and cardiovascular events (13-16). The persistence of high BP at night is a burden for the cardiovascular system with a negative impact on heart and blood vessels because there is no need for a high BP for the organ perfusion. The prevalence of nondipping is very frequent in patients with resistant hypertension. We have noticed an improvement of $31.3 \%$ of the pathological diurnal rhythm in cases where the patients reached the target BP values, whereas in the group of treatment-resistant patients the improvement was only $17.4 \%$ (Fig. 1). Hence, we hypothetize that the recovery of the pathological diurnal rhythm leads to better BP control. We did not manage though to define the factors, which led to diurnal rhythm improvement.

In the group of well controlled hypertensive patients we observed a slight, but statistically significant reduction in weight. A decline of blood creatinin and urea levels and albumin/creatinin ratio in urine was noticed by achieving the target BP values. It has been proven that microalbuminuria is more frequent presented in patients with impaired diurnal profile (17), and therefore a significant decline of albumin/creatinin ratio in urine in controlled hypertensives was presumably reached due to a recovery of pathological diurnal profile.

\section{Conclusion}

Hypertension represents a serious worldwide and socio-economic problem. The target BP values are not achieved in satisfactory level. Adequate BP control is the most problematic in patients with resistant hypertension. We do not have the data about the treatment effectiveness of these patients. The ethiology of the resistant hypertension is multifactorial. Although the factors 
associated with the resistant hypertension are well known, their contribution can be only estimated. According to the results of our work, this often relates to the high-risk patients with risk factors, co-illnesses and severe organ damage. Poor control of these risk factors (obesity, diabetes mellitus, hyperlipoproteinemia, etc.), advanced alternations of organ systems participating on the BP control, a damaged diurnal profile as well as the human factor (insufficient co-operation of the patients) are responsible for the treatment resistance. In these cases, the target BP values are often not achieved even by a high number of antihypertensive drugs. Based on our results we suppose that not even the selection of drugs is essential for achieving the target BP values because this strategy was equivalent in both groups of patients. However, the chronotherapy could be adequate because the treatment divided into more doses per day led to an improved pathological diurnal profile and subsequently to an improved BP control $(18,19)$. Yet we did not manage to define the factors leading to the improvement of the pathological diurnal rhythm. Resistant hypertension requires a multidisciplinary approach with the rigorous control of all the comorbidities, which lead to a higher morbidity and mortality in comparison with the general population of hypertensive patients.

\section{References}

1. Kearney PM, Whelton M, Reynolds K et al. Global burden of hypertension: analysis of worldwide data. Lancet 2005; 365 (9455): 217-223.

2. Filipová S, Mikeš Z, Tkáč I et. al. Komentár Slovenskej kardiologickej spoločnosti, spolupracujúcich odborných spoločností a d’alších odborníkov k Súhrnu európskych odporúčaní pre prevenciu kardiovaskulárnych ochorení v klinickej praxi. Cardiol 2008; 17 (Suppl 3): 37S-41S.

3. Sninčák M. Artériová hypertenzia. Súčasný stav na Slovensku, porovnanie so zahraničím, priority, odporúčania. 115-118. In: Kamenský G, Murín J et al. Kardiovaskulárne ochorenia - najväčšia hrozba. Biela kniha. Bratislava; AEPress, s.r.o., 2009.

4. Baráková A. Vývoj úmrtnosti v Slovenskej republike a v modelovom okrese Banská Bystrica v rr. 1992-1998 so zretel’om na úmrtnost' ochorení obehovej sústavy. In: Implementácia CINDI programu v SR v rr. 19921999. ŠZÚ Banská Bystrica 2000; s. 7.

\section{Sninčák M, Balažovjech I, Macháčová E. 2006.}

6. Kamenský G. Kontrola tlaku krvi u špecialistov, socio-ekonomické aspekty hypertenzie, povedomie obyvatel'stva o hypertenzii, Národný program prevencie ochorení srdca a ciev, možné riešenia a odporúčania. 126-134. In: Kamenský G, Murín J et al. Kardiovaskulárne ochorenia najväčšia hrozba. Biela kniha. Bratislava; AEPress, s.r.o., 2009.

7. Audičová M, Hrubá F. Genetické a exogénne rizikové faktory aterosklerózy vo všeobecnej slovenskej populácii - výsledky štúdie v rámci programu CINDI. Intern Med 2002; 2: 467-472.
8. Baráková A. Vybrané informácie zo zdravotníckej štatistiky o vývoji chorôb obehovej sústavy v SR. ŠZÚ v spolupráci s ÚZIaŠ. Bratislava. Projekt MONIKA 2002: 66.

9. The Task Force for the Management of Arterial Hypertension of the European Society of Hypertension (ESH) and the European Society of Cardiology (ESC). 2007 guidelines for the management of arterial hypertension. J Hypertens 2007; 25: 1105-1187.

10. Calhoun DA, Jones D, Textor S et al. Hypertension 2008; 51: 1403-1419.

11. Oliveras A, Sierra AL. New developments in the diagnosis and management of resistant hypertension. Curr Med Chem 2012; 19 (8): 12101218.

12. Acelajado MC, Pisoni R, Dudenbostel T et al. Refractory hypertension: definition, prevalence, and patient characteristics. J Clin Hypertens 2012; 14 (1): 7-12.

13. Armario P, Oliveras A, Hernández Del Rey R, Ruilope LM, De La Sierra A; Grupo de Investigadores del Registro de Hipertensión refractaria de la Sociedad Española de Hipertensión/Liga Española para la Lucha contra la Hipertensión Arterial (SEH-LELHA). Prevalence of target organ damage and metabolic abnormalities in resistant hypertension. Med Clin (Barc) 2011; 137 (10): 435-439.

14. Verdecchia P, Porcellati C, Schillaci G et al. Ambulatory blood pressure: an independent predictor of prognosis in essential hypertension. Hypertension 1994; 24: 793- 801 .

15. Staessen JA, Thijs L, Fagard R, et al; for the Systolic Hypertension in Europe (Syst-Eur) trial investigators. Predicting cardiovascular risk using conventional vs ambulatory blood pressure in older patients with systolic hypertension. JAMA 1999; 282: 539-546.

16. Ohkubo T, Hozawa A, Yamaguchi J et al. Prognostic significance of the nocturnal decline in blood pressure in individuals with and without high 24-h blood pressure: the Ohasama study. J Hypertens 2002; 20: 2183-2189.

17. Pimenta E, Calhoun DA. Resistant hypertension: incidence, prevalence, and prognosis. Circulation 2012; 125 (13): 1635-1642.

18. Bianchi S, Bigazzi R, Baldari G, Sgherri G, Campese VM. Diurnal variations of blood presure and microalbuminuria in essential hypertension. Am J Hypertens 1994; 7: 23-29.

19. Almirall J, Comas L, Martínez-Ocaña JC, Roca S, Arnau A. Effect of chronotherapy on blood pressure control in non-dipper patients with refractory hypertension. Nephrol Dial Transplant 2012; 27 (5): 1855-1859.

20. Hermida RC, Ayala DE, Fontao MJ, Mojón A, Fernández JR. Chronotherapy with valsartan/amlodipine fixed combination: improved blood pressure control of essential hypertension with bedtime dosing. Chronobiol Int 2010; 27 (6): 1287-1303.

21. Hermida RC, Ayala DE, Mojón A, Fontao MJ, Fernández JR. Chronotherapy with valsartan/hydrochlorothiazide combination in essential hypertension: improved sleep-time blood pressure control with bedtime dosing. Chronobiol Int 2011; 28 (7): 601-610.

Received February 24, 2012. Accepted May 2, 2012. 